\title{
Preparation and consumer acceptability tests of fermented camel milk in Kenya
}

\section{Journal Article}

Author(s):

Farah, Zakaria; Streiff, Thomas; Bachmann, Marc R.

Publication date:

1990

Permanent link:

https://doi.org/10.3929/ethz-b-000422799

Rights / license:

In Copyright - Non-Commercial Use Permitted

Originally published in:

Journal of Dairy Research 57(2), https://doi.org/10.1017/S002202990002690X 


\title{
SHORT COMMUNICATION
}

\section{Preparation and consumer acceptability tests of fermented camel milk in Kenya}

\author{
BY ZAKARIA FARAH, THOMAS STREIFF AND MARC R. BACHMANN \\ Laboratory of Dairy Science, Swiss Federal Institute of Technology, ETH-Zentrum, \\ CH-8092 Zürich, Switzerland
}

(Received 3 April 1989 and accepted for publication 16 October 1989)

There are estimated to be 600000 camels (Camelus dromedarius) in Kenya (Wandera, 1985). Almost $80 \%$ of these are kept by pastoral tribes living in arid areas in eastern and north-eastern parts of the country. In these regions, camels are important dairy animals. A camel in north-east Kenya can be expected to yield about $4 \mathrm{~kg}$ milk daily as compared with $0.5-1.5 \mathrm{~kg}$ for a cow in the same area. Most of the camel milk is consumed in the form of fermented milk. The milk is allowed to ferment naturally at ambient temperature and without prior heat treatment until it turns sour. The resulting fermented camel milk is known as Susa. Due to the spontaneous nature of the fermentation, this traditional method results in a product with varying taste and flavour and is often of poor hygienic quality. In addition, because of the limited scale of production, the product can be sold only in the immediate vicinity of the herd. For production of fermented milk under controlled conditions, thermophilic or mesophilic lactic acid cultures are normally used. In warm countries, mesophilic lactic cultured milk offers some advantages, as it can be incubated at ambient temperature $\left(20-30^{\circ} \mathrm{C}\right)$ and the fermentation stops at $1-1.2 \%$ lactic acid, eliminating the need for cooling to stop further souring as occurs in the case of yoghurt (Kurwijila, 1980).

Considering these advantages, Kurwijila (1980) developed, in Kenya, fermented cows' milk using mesophilic lactic cultures. Tests conducted with adult Kenyans showed high consumer acceptability.

The present investigation was undertaken in Garissa, a north-eastern province town of Kenya, where a majority of the population subsists almost entirely on camel milk. The objective of this study was to develop fermented camel milk using mesophilic lactic culture and to test the acceptability of the product in comparison with the traditional fermented camel milk.

\section{EXPERIMENTAL}

Milk samples

Fresh camel milk was obtained from herds owned by nomads around the town of Garissa. 


\section{Cultures}

Multiple strain, mixed type, lyophilized, mesophilic lactic cultures, O-CH:143 (homofermentative) and B-CH :40 (heterofermentative) were obtained from Chr. Hansen's Laboratorium, Denmark.

\section{Preparation of fermented milk}

Two 10-l churns of fresh whole camel milk were placed in a container filled with water and heated until the milk attained $85^{\circ} \mathrm{C}$. This temperature was maintained for $30 \mathrm{~min}$. After cooling in a water bath to ambient temperature, each milk churn was inoculated with $2 \%$ of a $24 \mathrm{~h}$ culture and incubated at a room temperature of $27^{\circ} \mathrm{C}$ for $24 \mathrm{~h}$.

\section{Chemical analysis}

For each milk the following parameters were determined; acidity by titration expressed in Soxhlet-Henkel degrees $\left({ }^{\circ} \mathrm{SH}\right)$, fat by the Gerber method, total solids by calculation after Fleischmann (1896) from the values of fat content, and specific gravity using a lactometer. The same determinations were also made with the traditionally fermented camel milk, Susa, from the local market.

\section{Sensory evaluation}

In the sensory tests, the two fermented camel milk samples were compared with a traditionally fermented camel milk, Susa. Two groups of people were selected for the sensory evaluation. Group A consisted of 13 Somali nomads with no formal education. All claimed to consume Susa regularly. Group B consisted of nine Somalis and three Canadians. They all worked as senior officers in the Provincial and District Administrations. Seven of the group reported consuming Susa regularly and five only occasionally.

As the panellists had no previous experience of testing products, the rating test was simplified and limited in respect of consumer preference. Each person was asked to taste the three coded samples and score each product for preference on a threepoint scale ranging from 'most preferred' (preference score $=1$ ) to 'least preferred' (preference score $=3$ ). The instructions were given orally in both the Somali and English languages. The panellists were told that they were testing camel milk, but the identities of the individual samples were revealed only after the tests were completed.

\section{RESULTS AND DISCUSSION}

Compared with cows' milk, the consistency of fermented camel milk is thin. After fermentation a precipitate in the form of flocs was formed rather than a coagulum. In a preliminary experiment an attempt was made to improve the consistency by the addition of cows' milk powder. However, this had to be omitted in the final experiments, as sensory evaluation and conversation with consumers of camel milk revealed that mixing camel with cows' milk affected the typical camel milk taste and was undesired.

Results of chemical and sensory analysis are presented in Table 1 . The values of total solids and fat content were the same in all the samples. Homofermentative culture O-CH:143 showed less titratable acidity. Fermented milk made with mesophilic lactic cultures was clearly preferred by both groups. Within the two 
Table 1. Test panel preference scores of three fermented samples of camel milk

\begin{tabular}{|c|c|c|c|}
\hline \multirow{3}{*}{$\begin{array}{c}\text { Sensory } \\
\text { evaluation }\end{array}$} & \multicolumn{3}{|c|}{ Fermented samples of camel milk } \\
\hline & \multicolumn{2}{|c|}{ Mesophilic lactic cultures } & \multirow[b]{2}{*}{ Susa } \\
\hline & $\mathrm{O}-\mathrm{CH}: 143$ & $\mathrm{~B}-\mathrm{CH}: 40$ & \\
\hline $\begin{array}{l}\text { Group } A, n=13 \\
\text { Mean score } \\
\text { s.d. }\end{array}$ & $\begin{array}{l}2 \cdot 08 \\
0 \cdot 76\end{array}$ & $\begin{array}{l}1 \cdot 39 \\
0 \cdot 77\end{array}$ & $\begin{array}{l}2 \cdot 31 \\
0 \cdot 86\end{array}$ \\
\hline $\begin{array}{l}\text { Group } B, n=12 \\
\text { Mean score } \\
\text { s.d. }\end{array}$ & $\begin{array}{l}1 \cdot 58 \\
0 \cdot 67\end{array}$ & $\begin{array}{l}1 \cdot 50 \\
0.52\end{array}$ & $\begin{array}{l}2 \cdot 92 \\
0 \cdot 29\end{array}$ \\
\hline $\begin{array}{c}\text { Chemical analysis } \\
\text { Total solids, \% } \\
\text { Fat content, \% } \\
\text { Acidity }{ }^{\circ} \mathrm{SH}\end{array}$ & $\begin{array}{r}12 \cdot 7 \\
4 \cdot 1 \\
36 \cdot 2\end{array}$ & $\begin{array}{r}12 \cdot 7 \\
4 \cdot 0 \\
40 \cdot 0\end{array}$ & $\begin{array}{r}12 \cdot 5 \\
4 \cdot 0 \\
40 \cdot 0\end{array}$ \\
\hline
\end{tabular}

starter cultures used, the homofermentative culture $\mathrm{O}-\mathrm{CH}: 143$ was least preferred. Both groups described the two prepared cultured milks as particularly good Susa with uniform fresh taste. The study shows that the traditional Susa can be improved by using selected mesophilic lactic acid culture. Seasonal variations in camel milk production are great in north-eastern Kenya, and much surplus milk is wasted during the rainy season (R. Muriuki, pers. comm.). The method described here for fermented milk production can be introduced in rural areas. It allows small-holder producers to process surplus milk on-farm or in centralized small-scale units. Obtaining starter culture could be a limiting factor for large-scale production of fermented milk. However, simple commercial systems for producing frozen starter cultures which maintain their activity for years are in operation in Kenya (Kurwijila, 1983; Schulthess, 1988).

We thank the staff of Garissa Community Service Centre in Kenya for providing us with all the facilities during our field work.

\section{REFERENCES}

Fleischman, W. 1896 The Book of the Dairy, pp. 71-72.

KuRwiJiLA, R. L. N. 1980 Low cost optimization of the flavour, consistency and keeping quality of fermented milk with particular reference to consumer acceptibility in Kenya. M.Sc. Thesis, University of Nairobi

KurwiJiLA, R. L. N. 1983 Maintenance of reactivated, lyophilised mixed type lactic cultures by subculturing and by cold storage. Indian Journal of Dairy Science 36 338-343

Schulthess, W. 1988 [Appropriate milk product development-an example in Kenya.] LebensmittelTechnologie 21 226-228

Wandera, J. G. 1985 Camel pastoralism in Kenya. In Significance and Prospects of Camel Pastoralism in Kenya pp. 61-62 (Ed. S. E. Migot-Adholla), Nairobi, Kenya: Institute for Development Studies 